\title{
Perceived Benefits of Using Value Engineering on Road Projects in Ghana
}

\author{
James Cofie Danku1, Philip Agyekum Antwi² \\ ${ }^{1}$ Department of Construction Technology and Management, Kwame Nkrumah University of Science and Technology, Kumasi, \\ Ghana \\ ${ }^{2}$ Donald-Wonders GeoSystems Ghana Limited, Kumasi, Ghana \\ Email: jmcdanku@yahoo.com
}

How to cite this paper: Danku, J.C. and Antwi, P.A. (2020) Perceived Benefits of Using Value Engineering on Road Projects in Ghana. World Journal of Engineering and Technology, 8, 217-236.

https://doi.org/10.4236/wjet.2020.82018

Received: April 28, 2020

Accepted: May 15, 2020

Published: May 18, 2020

Copyright $\odot 2020$ by author(s) and Scientific Research Publishing Inc. This work is licensed under the Creative Commons Attribution International License (CC BY 4.0).

http://creativecommons.org/licenses/by/4.0/

\begin{abstract}
The need for Optimum Value benefit realization on Road Projects in developing countries has become topical. While the traditional Cost Control project management process only aligns actual costs with budgeted costs, Value Engineering (VE) is a sustainable and systematic innovative methodology for establishing the best functional balance among desired features of a project. A Value Engineering (VE) study was conducted with the aim of examining the benefits associated with its use on Road Projects in Ghana. This study employed a two-stage research procedure: desk study and field research. The literature review identified the Optimum Value benefits associated with VE road project management technique as increased Confidence Level in Contract Compliance, reliable Implementation Level of Construction Delivery and enhanced Effectiveness Level of Project Sustainability. A quantitative survey research design based on a purposive sampling technique of selecting respondents was adopted. Employing closed-ended questions, 40 sets of questionnaires were issued to professionals in Road Infrastructure and Support Agencies (RISA) under the Ministry of Roads and Highways (MRH) in the Eastern Region of Ghana. At a response rate of 85\%, descriptive statistical analysis (Means, Standard Deviations and Variances) and inferential statistical analysis of variance (ANOVA) test were used to process the data and determine whether there was any significant difference between VE benefit parameters and the groups of respondents. The results revealed that road professionals are familiar with the VE process but solely use Cost Control project management technique. Road professionals recognized the high Optimum Value benefits of professionally ethical Contract Compliance, efficient Construction Delivery and functionally viable Project Sustainability on VE road project management process.
\end{abstract}




\section{Keywords}

Optimum Value, Cost Control, Value Engineering, Road Projects, Ghana

\section{Introduction}

Road Projects are capital intensive therefore require optimum service quality for cost-effectiveness. Rapid innovations in technology necessitate a critical look at existing project management processes in order to enhance quality delivery and sustainability [1] [2]. Road Projects in Ghana have, hitherto, employed the Cost Control project management process of achieving Value. According to Chileshe et al. [3], Value Engineering (VE) is not a popular project management process in the road construction sector; a major reason for the incessant excessive project cost overruns, poor quality, excessive time overruns and poor functional features on road projects. Dzah's [4] study of the Ghanaian construction industry recognized that Consultants critically differentiated between mere Cost Control and VE project management processes. VE maintains a sustainable balance among project management process parameters. When the potential of VE practice is not harnessed, optimum value benefits cannot be achieved. Kissi et al. [5] also asserted that although VE presents a solution to the existing myriad of project management challenges, the concept is yet to find a niche in the construction industry of Ghana. It is therefore abstruse to state with any conviction that VE process components are employed on road projects [6] [7].

$\mathrm{VE}$ is a comprehensive strategy for the management of costs, time, quality and safety standards with the ultimate goal of guiding the work to achieve optimum value [8] [9]. Cost Control project management techniques do not guarantee quality or value. However, optimum value benefits can be realized through the VE process. This is attained by instituting VE multidisciplinary teams as a supplement to the existing interdisciplinary project teams. Besides, Value Clauses are introduced in the contract documents and a method enhancement incentive program is encouraged to enable contractors to gain rewards for optimizing construction techniques on projects; ultimately promoting a cost-saving VE incentive program on projects [10] [11] [12]. Developing asset management responsibility action plans for teams also boosts VE on projects.

The study is based on the research gap that no Optimum Value benefits have been realized on Road Projects execution so far in Ghana with the existing Cost Control project management process. The aim of the research is to assess the benefits associated with the use of VE technique on Road Project management in Ghana, from the Road Professionals' perspective. In order to achieve this, the study will seek to address the research question on the benefits associated with Value Engineering. This question will be answered by drawing on comparative studies between two main project management processes of Value Engineering (VE) and the Cost Control respectively. It is very important to note that the gap 
between these two processes is the functional element of Value [13]. Whereas the Cost Control process seeks to regulate cost within project budget [7] [14], the VE process maintains a sustainable balance among all project budget requirements to improve Value [15].

\section{Literature Review}

\subsection{Road Projects in Ghana}

Roads contribute significantly to the economic infrastructural development of a country. Road transportation is overwhelming the most widely employed means of traversing Ghana. Agriculture, Mining, Manufacturing, Construction and other socio-economic activities thrive on the sustainable management of the road. Roads link all major cities, towns, villages, agricultural production areas and other economic activities with local, regional and national markets. These are essential for enhancing socio-economic activities in the country [16] and stimulating growth and development [17]. Road Projects in Ghana require huge capital investment [18]. Without corresponding optimum values being realized, the high investment becomes acceptable, unjustifiable and a colossal economic aberration and deficit. The Ministry of Roads and Highways (MRH) is the Agency in charge of road project management and administration, road construction, road rehabilitation and maintenance, as well as, road safety and the environment in Ghana [19]. It comprises the following main agencies: Ghana Highway Authority (GHA), Department of Urban Roads (DUR), Department of Feeder Roads (DFR), the Koforidua Training Centre (KTC) and the Ghana Road Fund Secretariat (GRFS). Road networks in Ghana are classified as trunk roads (regional, inter-regional and inter-national corridor roads), feeder roads (rural roads) and urban roads (metropolitan and municipal roads); being managed by GHA, DFR and DUR, respectively. The vision of the MRH is to provide and retain a combined, economical, harmless and supportable road transport network receptive to the needs of users, supporting development and poverty alleviation. The mission of the ministry is to transport the mandatory guidelines, monitor and assess packages and projects to safeguard the delivery of inexpensive, combined, innocuous, receptive and supportable road transport network that will meet the financial, communal and ecological needs as well as national and international principles. All Road Projects in Ghana are developed and managed as follows [19]:

1) Inventory, Design, Estimation and Project packaging;

2) Preparation of Tender and Contract Documents;

3) Invitation for Bids and Expression of Interests;

4) Evaluation of Bids;

5) Award of Contracts;

6) Supervision/Monitoring and Award of Projects/Contracts;

7) Preparation and Certification of Payment Certificates;

8) Preparation of Monthly, Quarterly and Annual Reports; 
9) Post Audit/Project Completion Reporting;

10) Conduction of Road Condition Survey.

There is a need for systematized approach to this process with the objective to achieve the best balance among these factors for optimum cost, reliability and overall project performance. This important link between design through construction to maintenance, which is the focus of VE, is not well established in the Ghanaian road sector. No VE component is incorporated into the development and management strategies of the process. There is a fixation on Cost Control structure [19] thereby restricting all aspects of the work to budget considerations [6]. This narrow view invariably pays little attention to the greater Value Optimization deliberation.

\subsection{Optimum or Best Value}

SAVE International [20] views Value as a fair return on properties, facilities or cash for scheme or project. Realizing true worth becomes an objective, and it is met by analyzing the functions of systems and resources available for use to fulfill the functions. SAVE International [20] recommends that the function should be measured by performance requirements while resources to be measured in terms of materials, labor, prices or cost and time. Kasi [21] indicated that Value is accomplished when the project has a high performance by reaching the desired acceptance at a reasonable cost. The Value of any road construction project is the performance of its owner functional requirements (budget or cost value, time value, quality value, scope value, among others) at the lowest life-cycle costs [22]. The ultimate approach to optimizing Value is maintaining a balance among all owner functional project features by increasing Value rather than reducing Costs [23]. Based on this, there is a need to analyze Value for optimized results [24] [25]. Value is the ratio of Function (Quality or Performance or Worth) to Cost (Price you pay or Resources). Thus "Optimum or Best Value" is determined by the ratio of Functional Requirements (Desired Customer Performance or Quality or Worth) to Lowest Life Cycle Cost [26]. There is, therefore, the need for high Functional Requirement at the least Life Cycle Cost for Optimum or Best Value to be accomplished [27] [28].

\subsection{Cost Control Project Management Process and Optimum Value Deficiencies}

Cost Control project management process is the ultimate process of project cost management [29] [30], which seeks to analyze and manage cost with basic processes of resource planning, cost estimation and cost budgeting [29] so that the project budget is not exceeded [31]. Limitations in Value exist in this project management process; thus, a contemporary project management process should be directed towards achieving an Optimum Value [32]. The Cost Control process on Road Projects in Ghana has over the years resulted in imbalances in the project management requirements of Road Projects such as excessive cost overruns (deviations in contract sums as against final accounts), excessive time 
overruns, unsatisfactory quality and poor safety and environmental practices [6] [7] [14] [33] [34]. This Cost Control process has rendered most Road Projects functionally unsustainable. Road Professionals in their effort to manage Road Projects need to establish equilibrium between their strategic and operational concerns [35].

\subsection{Value Engineering (VE) Project Management Process and Optimum Value Benefits}

Value Engineering (VE) project management process is a sustainable, systematic and innovative methodology for establishing the best functional balance among the desired features or requirements of a project [36] [37]. VE, also known as Value Planning (VP); Value Analysis (VA), Functional Analysis (FA) or Value Management (VM) it is a multi-faceted concept that has many requirements including knowledge of project systems, cost estimating and working in multidisciplinary teams [21] [23] [24] [38]. The best time for applying VE is at the planning and early design stage (Figure 1). Changes effected at this stage will result in major cost savings to the owner without expensive change orders [10] [39]. On the other hand, VE can be applied during the construction phase when there is a contractor-incentive sharing clause where a contractor may be allowed to share in the savings resulting from his/her recommendations for cost-reduction [23]. A multidisciplinary team has proved to be the most effective structure for a VE study [40] [41]. The VE process is applied by this team to improve the value of a project through the analysis of functions [42]. It is a two-stage process: the VE Job Plan and VE Methodology [23] [43].

The VE Job Plan consists of the following sequential phases or study processes (Figure 2):

1) Information phase-“Project High-Cost Component Determination" phase.

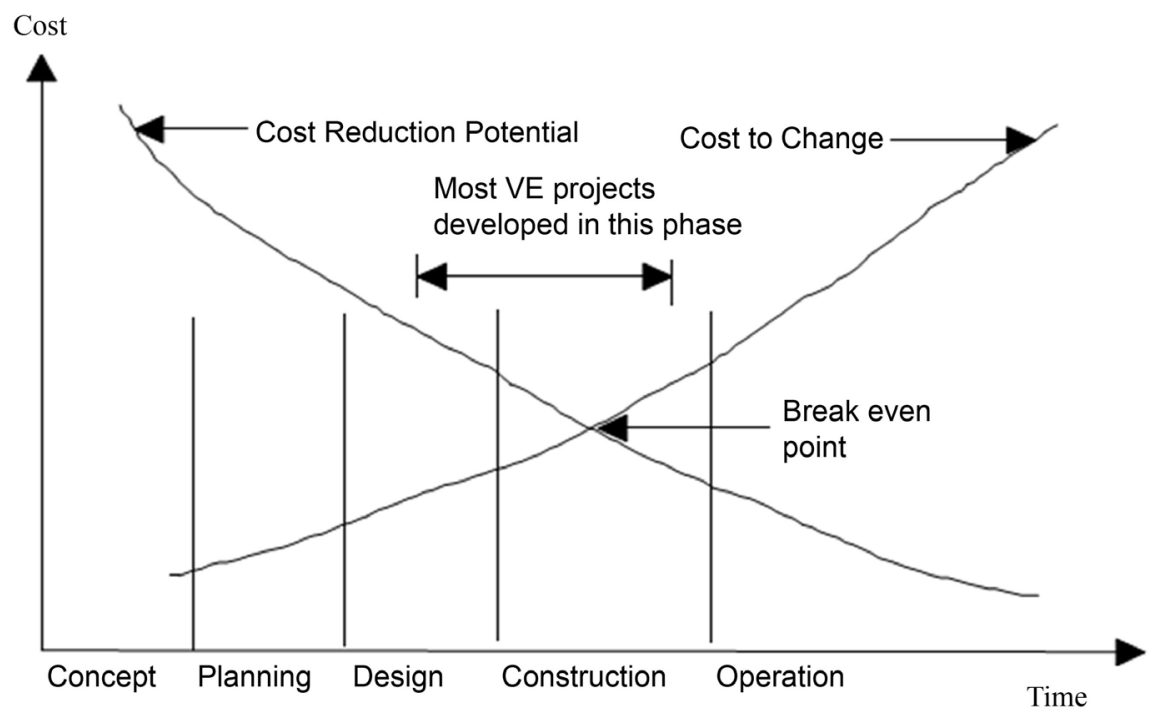

Figure 1. Cost reduction potential (Cost) vs. Cost to change (Time) (Source: DelP Isola, 1982) [39]. 


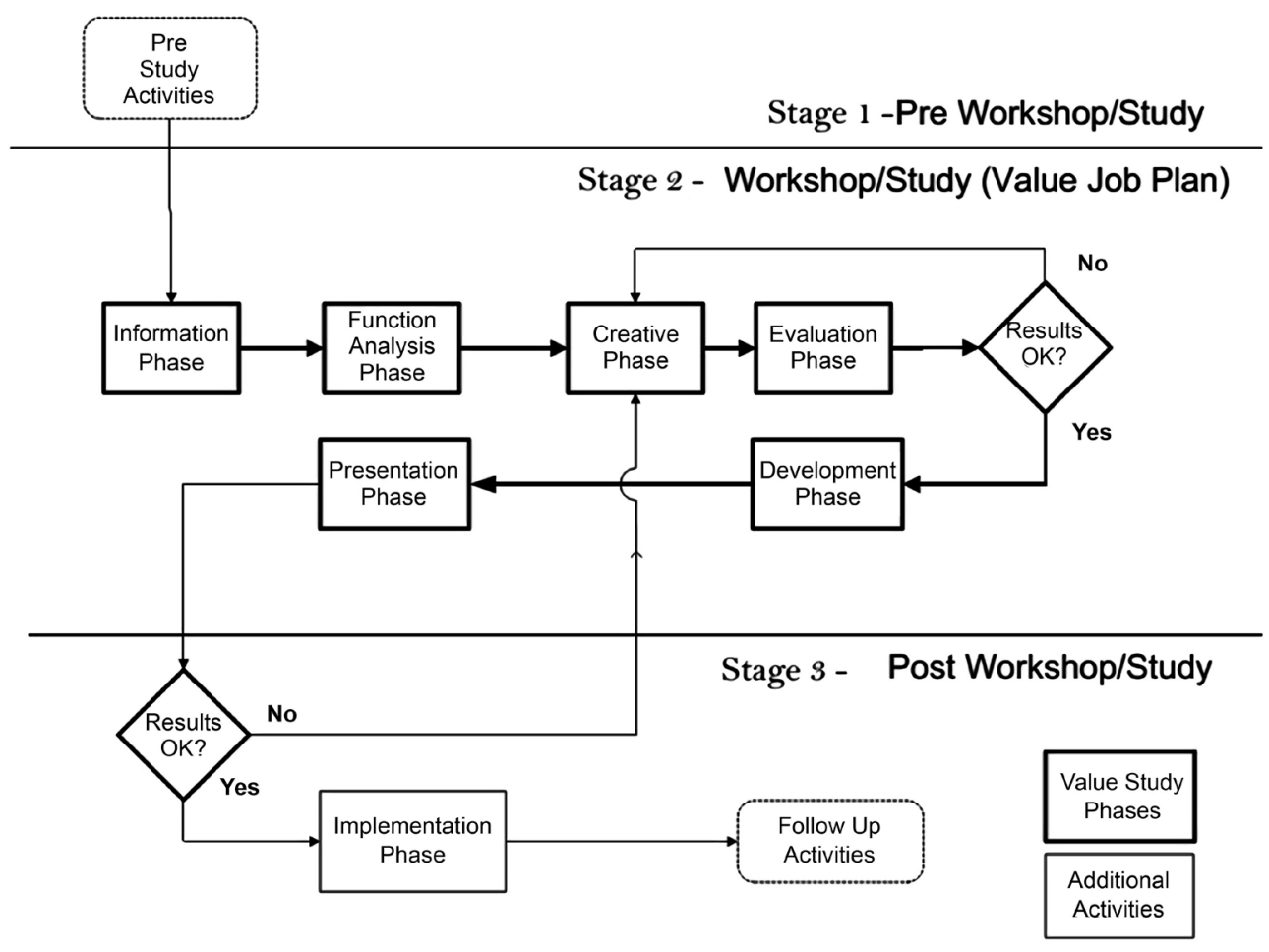

Figure 2. The value study process flow diagram (Source: SA VE, 2007) [44].

2) Function Analysis (FA) - "Functions and Activities Determination" phase.

3) Speculative- "Creation of Alternatives" phase.

4) Evaluation- “Cost Allocation and Analysis" phase.

5) Development phase- “Optimum Alternative Selection" phase.

6) Presentation phase- "Best Alternative Reporting" phase.

7) Implementation phase- "Strategies for the Implementation of Best Alternative" phase.

8) Final Acceptance phase- "Defense of Implementation Plan to Owner" phase.

The typical Function Analysis System Technique (FAST) or VE Methodology is shown in Figure 3 [45]. The formal approach to the VE Methodology is as follows [46] [47] [48] [49]:

1) The Charette Methodology-administered by the design team at the end of the compilation of the project brief but prior to the design phase;

2) The 40-Hour Workshop Methodology-a weeklong VE study undertaken by a second and independent design team to review preliminary designs;

3) The Value Engineering Change Proposal (VECP) Methodology-Contractors deliver alternative but economically feasible designs, elements, specifications or method statements.

In the management of Road Projects, detailed components of the road to be constructed such as bridges, drains, culverts, subgrade, subbase, base, wearing course, road markings, kerbs, medians, among others, can be subjected to a VE analysis in order to optimize the overall Value of the Road Project. In his study 


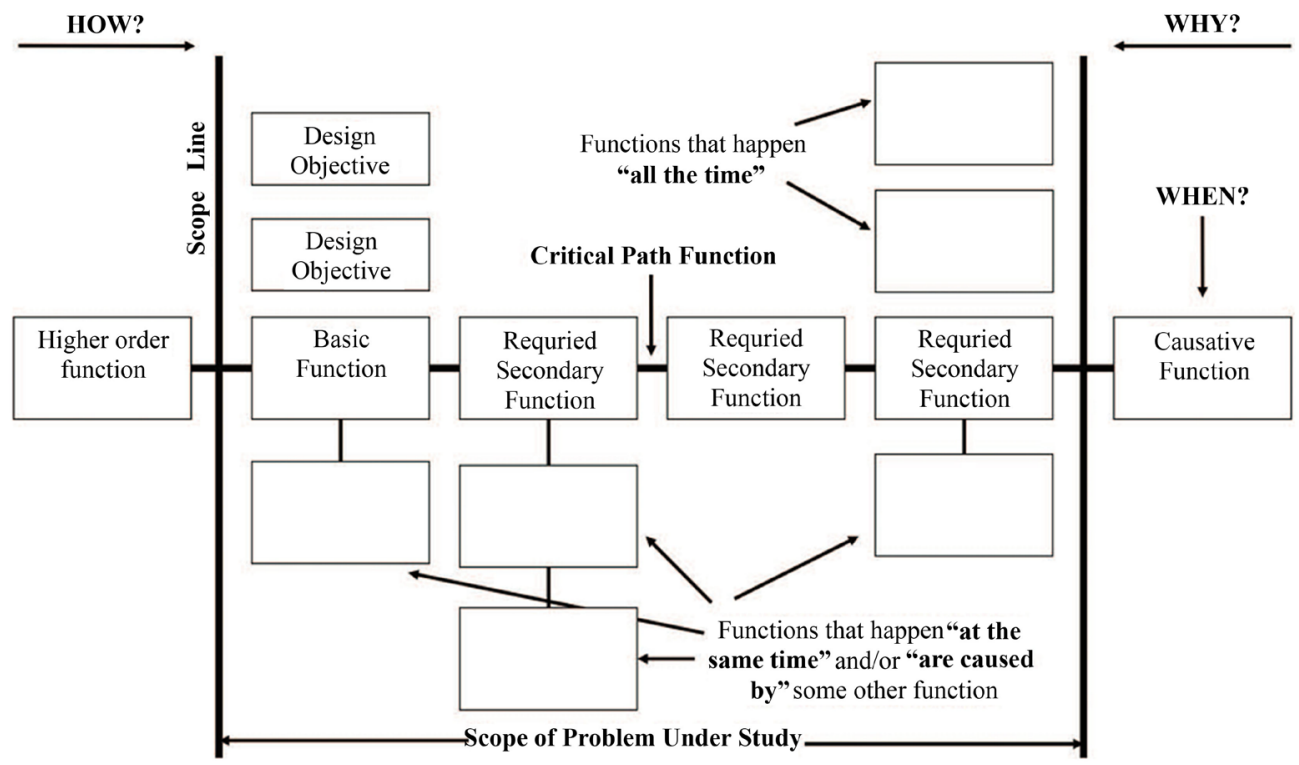

Figure 3. The VE functional analysis system technique (FAST) (Source: Jarboe, 1978) [45].

of a highway bridge construction, Jarboe [45] demonstrated that a saving of $14.3 \%$ on the original design was attained through the application of the FAST technique.

VE has the propensity of optimizing the Value on projects in three different dimensions:

\section{1) Contract Compliance Optimum Value benefit}

Contract Compliance (CC) on projects is a state of acting in conformance with the predefined and agreed rules, contract clauses or guidelines to meet the stated and implied needs of the project client or beneficiary. In terms of contract compliance, the use of VE will be professionally ethical during the planning and design stage for Optimum Value benefits if it meets the stated and implied needs of clients, reduces life cycle costs, decreases timelines, optimizes Value, improves quality and functional performances. The application of VE at an early stage will be justified if it breaks high costs and low efficiencies, averts excessive variations, enhances project teams, enhances project schedules and isolates design deficiencies [42] [49]. The confident level (CL) measures the Contract compliance status.

\section{2) Construction Delivery Optimum Value benefit}

Construction Delivery (CD) deals with different ways to organize construction services to execute a project. In terms of $\mathrm{CD}$, the use of VE will be considered efficient during construction stage for Optimum Value benefits if Value is an avenue to address quality or not to be equated to money. Value is client-centered (human process), precede product (project) and based on analysis of the functional elements. Other considerations are whether Cost is reduced, Time is saved and Quality is improved [23] [41]. Construction Delivery is assessed in terms of its Implementation level (IL).

3) Project Sustainability Optimum Value benefit 
Project Sustainability (PS) deals with procedures geared towards meeting the needs of the present generation but which will not affect the ability of the future generation to also address their economic, social and environmental impacts of the project. In terms of project sustainability, the use of VE will be functionally viable during the operation and maintenance stage for Optimum Value benefits. VE targets achieving the essential functions of the project components at the lowest life cycle costs and striving for a sustainable balance among all the project management parameters [30]. This will ultimately give rise to functionally viable projects [28]. The effectiveness level (EL) is a measure of Project Sustainability.

\section{Research Method}

This study adopted the literature review and survey approach based on a purposive sampling technique of selecting respondents [50] under the Ministry of Roads and Highways (MRH) from Koforidua in the Eastern Region of Ghana. This region was used for the study because it links a number of economically and socially significant highways from the southern to the northern parts of Ghana. Questionnaires were made up of categorical (nominal) data responses and continuous (ratio) data responses [51]. A total of thirty-four (34) questionnaires were successfully retrieved from forty (40) administered; representing $85 \%$ response rate. This high response rate was achieved as a result of the numerous follow-ups. These were then coded and subjected to statistical tests. In all, 13 respondents were from Department of Feeder Roads (DFR), 9 from Ghana Highway Authority (GHA), 7 from Department of Urban Roads (DUR) and 5 from the Koforidua Training Centre (KTC). These can be found in Table 1. Over $86 \%$ of the respondents were professionally affiliated (Figure 4 ).

Table 1. Road infrastructure and support agencies (RISA).

\begin{tabular}{ccccc}
\hline & Road Professionals & Frequency & Percentage & Cumulative Percentage \\
\hline \multirow{4}{*}{ Valid } & DFR (1) & 13 & 38.2 & 38.2 \\
& DUR (3) & 7 & 20.6 & 58.8 \\
& GHA (2) & 9 & 26.5 & 85.3 \\
& KTC (4) & 5 & 14.7 & 100.0 \\
\hline
\end{tabular}

\section{$13.2 \%$}

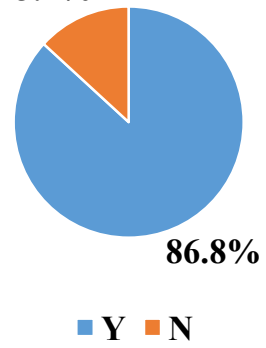

Figure 4. Professional affiliation of respondents. 
The statistical techniques used were Descriptive Statistics (Means, Standard Deviation and Variance) and Inferential Statistics (Parametric Analysis of Variance (ANOVA) tests). Descriptive Statistics deal with the analysis of datasets in terms of their measures of central tendencies (such as means) and measures of dispersion (such as standard deviations and variances); necessary to determine the normality of the distribution [52]. Parametric tests assume a normal distribution of the underlying population sample means with continuous (ratio) datasets [53]. The ANOVA tests became necessary because there was the need to compare two means from two independent (unrelated) groupings under the same dependent variable of Road Infrastructure and Support Agencies (RISA) of MRH. ANOVA tests were determined from the premise that the mean differences between and within groupings were the same [53] [54]. Data were analyzed using essential research analytical tools and techniques: Statistical Package for the Social Sciences (SPSS) and MS EXCEL [51] in order to examine the benefits associated with the use of VE on Road Projects in Ghana.

\section{Results}

Results were obtained from a questionnaire survey of professionals from the Department of Feeder Roads (DFR), Ghana Highway Authority (GHA), Department of Urban Roads (DUR) and Koforidua Training Centre (KTC). Responses from these professionals with the four institutions admitted to the high level of theoretical acquaintance with the concept of VE. In practice, however, Cost Control management processes were commonly used for the road project. From Figure 5, only 5.9\% of the respondents admitted to applying VE principles. The majority (94.1\%) of professionals did not have any practical knowledge on VE.

The respondents' perspectives on the individual and aggregate impacts of cost, time and quality on road projects were also assessed. The basis was to test the professionals' perceptions of these parameters towards the success of the project. The respondents were requested to select either independently or in any combinations, the basic project influential factors of cost, time or quality. The rationale was to compare the traditional cost control project management process to the harmonized VE technique. Each of the 34 respondents was allowed to select one or more of the five options available. The results of the effects of cost, time, quality independently and in any two combinations (cost + time, cost + quality and time + quality), as well as the net of all three (cost + time + quality) on value management of road projects, is presented in Figure 6. Thirty-one professionals indicated cost as the major factor impacting road projects success and viability. Seventeen and 21 considered time and quality as a major influencing factor towards road project success respectively. While 28 regarded any two combinations (COMB2) as critical; only 9 considered all three factors (ALL3).

The study was mainly aimed at examining the benefits associated with the use of VE on road construction projects. In this regard, the Optimum Value benefits 


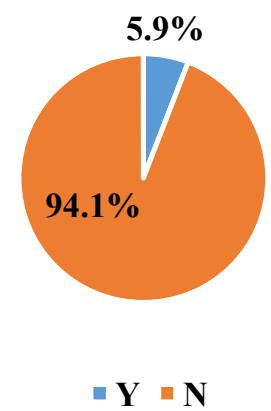

Figure 5. Practical knowledge of VE.

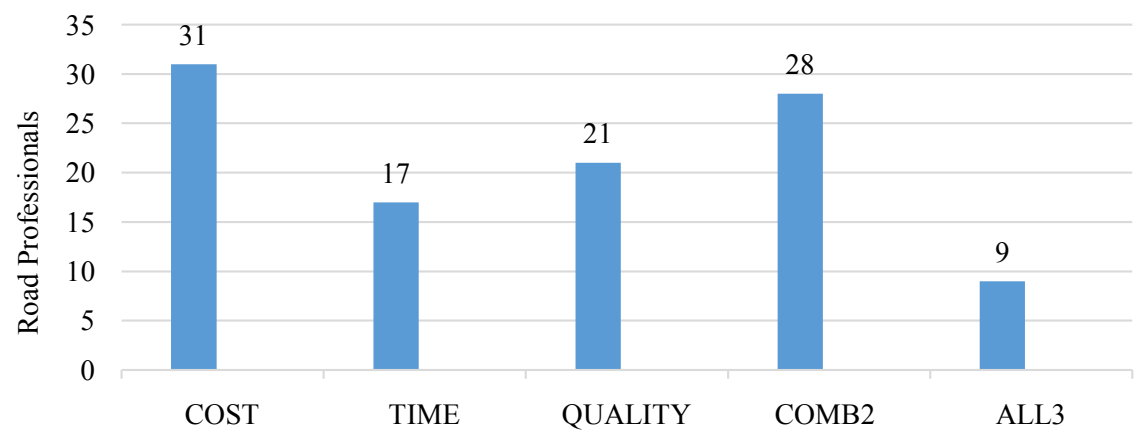

Figure 6. Impacts of project parameters on road construction.

of the VE process were identified and examined in three different dimensions under Contract Compliance (CC), Construction Delivery (CD) and Project Sustainability (PS). Contract Compliance was measured in terms of the Confidence Level (CL), Construction Delivery in Implementation Level (IL) and Project Sustainability in terms of Effectiveness Level (EL). Based on a five-point scale (where 1-Strongly Disagree, 2-Disagree, 3-Undecided, 4-Agree and 5Strongly Agree), the three factors were rated by the 34 road professionals in the Department of Feeder Roads (DFR), Ghana Highway Authority (GHA), Department of Urban Roads (DUR) and Koforidua Training Centre (KTC). The compressed line graphs of CL, IL and EL, which measured Contract Compliance (CC), Construction Delivery (CD) and Project Sustainability (PS) respectively, were drawn using the mean scores of respondents and is presented is in Figure 7.

All three VE benefit parameters of Confidence Level (CL) of the Contract Compliance, Implementation Level (IL) of contract Delivery and Effective Level (EL) of Project Sustainability were rated high by the respondents. The Confidence Level was rated by respondents from DFR, GHA, DUR and KTC at 3.95, $4.09,3.89$ and 3.69 respectively. This gave an overall mean score of 3.91 out of a maximum of 5. The Implementation Level which communicated the benefits of efficient Construction Delivery was rated with a mean score of 3.87 and departmental values of 3.99, 3.94, 3.83 and 3.72 for DRF, GHA, DUR and KTC. There were relative fluctuations in the responses of professionals with respect of Effectiveness Level with a high of 4.33 (GHA) and a low of 3.31 (DUR).

The Analysis of Variance (ANOVA), a parametric equivalence of the t-test, 


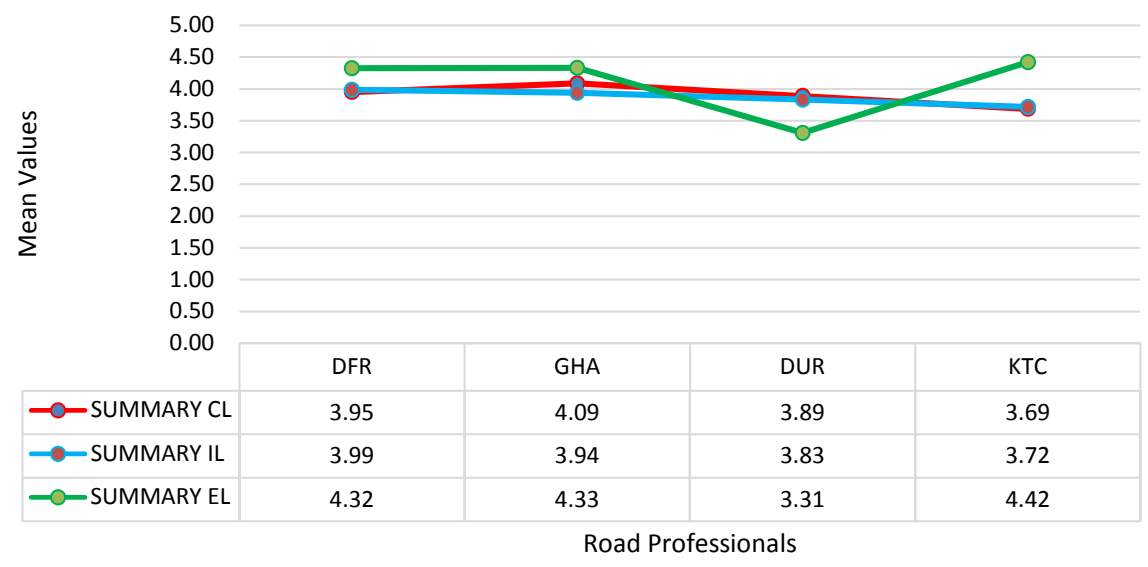

Figure 7. The three dimensions of optimum value benefits.

was used to determine whether there were any statistically significant differences between the group (DFR, GHA, DUR and KTC) means. The one-way ANOVA (analysis of variance) test descriptives, " $F$ ratio" and Post Hoc Multiple Comparisons (Tukey HSD) of responses of the four groups on benefits of CC, CD and PS are presented in Table 2 through to Table 4. The mean for each of the four groups, together with the "grand means" and "standard error" (the measure of the accuracy with which the sample distribution represents a population) at $95 \%$ confidence level are presented in Table 2. The grand means are 3.9348, 3.9031 and 4.3268 for CC, CD and PS respectively. The corresponding standard errors are $0.05371,0.04301$ and 0.03951 . This crucial ratio of "the between-groups" to "the within-groups" population variance estimate or the " $F$ ratio" (Table 3 ) for CC and CD are 1.974 and 1.761 (both greater than 1) while that of PS is 0.498 (lower than 1). Turkey's honest significant difference (Turkey HSD) test was used to compare the significant differences in responses of the DFR, GHA, DUR and KTC. For the CC benefit, $F(3,30)$ equals to $1.974, \mathrm{CD}$ for $F(3,30)$ equals 1.761 and PS for $F(3,30)$ equals 0.498 . In Table 4 , responses from each of the four groups were compared with every other, giving the mean difference between each pair, standard error and the probability values at $95 \%$ confidence level. It can be seen from the post-hoc test (Turkey HSD) that the differences between DFR and GHA, and DFR and DUR (with effective sizes of 0.6940 and 0.2391 ) were unlikely to have arisen by sampling error. Consequently, there were no significant differences between the DFR and GHA, and DFR and DUR regarding their perceptions on the Confidence Level (CL) expressed on Contract Compliance (CC) as Optimum Value Benefit.

\section{Discussions}

The Cost Control system is traditionally employed in the management of road project in Ghana. Cost Control project management process seeks to analyze and manage cost with basic processes of resource planning, cost estimation and budgeting [29]. Adjei et al. (2018) [14] identified excessive cost and overruns, 
Table 2. The one-way ANOVA test descriptives.

\begin{tabular}{cccccc}
\hline Optimum Value Benefit & RISA & N & Mean & Std. Deviation & Std. Error \\
\hline \multirow{2}{*}{$\begin{array}{c}\text { Contract Compliance } \\
\text { (CC) }\end{array}$} & GHA & 13 & 3.9498 & 0.26318 & 0.07299 \\
& DUR & 7 & 4.0870 & 0.13223 & 0.04408 \\
& KTC & 5 & 3.6870 & 0.58121 & 0.09528 \\
& Total & 34 & 3.9348 & 0.31321 & 0.05371 \\
& DFR & 13 & 3.9864 & 0.14238 & 0.03949 \\
Construction Delivery & GHA & 9 & 3.9412 & 0.26307 & 0.08769 \\
(CD) & DUR & 7 & 3.8319 & 0.25512 & 0.09643 \\
& KTC & 5 & 3.7176 & 0.37986 & 0.16988 \\
& Total & 34 & 3.9031 & 0.25078 & 0.04301 \\
& DFR & 13 & 4.3248 & 0.12391 & 0.03437 \\
& GHA & 9 & 4.3333 & 0.24845 & 0.08282 \\
Project Sustainability (PS) & DUR & 7 & 4.2540 & 0.20998 & 0.07937 \\
& KTC & 5 & 4.4222 & 0.42601 & 0.19052 \\
& Total & 34 & 4.3268 & $\mathbf{0 . 2 3 0 3 9}$ & $\mathbf{0 . 0 3 9 5 1}$ \\
\hline
\end{tabular}

RISA-Road Infrastructure and Support Agencies.

Table 3. ANOVA test statistics.

\begin{tabular}{|c|c|c|c|c|c|c|}
\hline $\begin{array}{c}\text { Optimum Value } \\
\text { Benefit }\end{array}$ & & $\begin{array}{l}\text { Sum of } \\
\text { Squares }\end{array}$ & Df & Mean Square & $\mathbf{F}$ & Significance \\
\hline Contract & Between Groups & 0.534 & 3 & 0.178 & 1.974 & 0.139 \\
\hline \multirow{2}{*}{$\begin{array}{l}\text { Compliance } \\
\text { (CC) }\end{array}$} & Within Groups & 2.704 & 30 & 0.090 & & \\
\hline & Total & 3.237 & 33 & & & \\
\hline Construction & Between Groups & 0.311 & 3 & 0.104 & 1.761 & 0.176 \\
\hline \multirow{2}{*}{$\begin{array}{l}\text { Delivery } \\
\text { (CD) }\end{array}$} & Within Groups & 1.765 & 30 & 0.059 & & \\
\hline & Total & 2.075 & 33 & & & \\
\hline Project & Between Groups & 0.083 & 3 & 0.028 & 0.498 & 0.686 \\
\hline \multirow{2}{*}{$\begin{array}{l}\text { Sustainability } \\
\text { (PS) }\end{array}$} & Within Groups & 1.669 & 30 & 0.056 & & \\
\hline & Total & 1.752 & 33 & & & \\
\hline
\end{tabular}

Table 4. The one-way ANOVA post hoc multiple comparisons-Tukey HSD.

\begin{tabular}{cccccc}
\hline $\begin{array}{c}\text { Optimum Value } \\
\text { Benefit (Dependent } \\
\text { Variable) }\end{array}$ & $\begin{array}{c}\text { (I) RISA } \\
\text { (Independent } \\
\text { Variable) }\end{array}$ & $\begin{array}{c}\text { (J) RISA } \\
\text { (Independent } \\
\text { Variable) }\end{array}$ & $\begin{array}{c}\text { Mean } \\
\text { Difference } \\
\text { (I-J) }\end{array}$ & $\begin{array}{c}\text { Standard } \\
\text { Error }\end{array}$ & Significance \\
\hline \multirow{2}{*}{$\begin{array}{c}\text { Contract Compliance } \\
\text { (CC) }\end{array}$} & DFR & GHA & -0.1371 & 0.1302 & 0.720 \\
\cline { 2 - 6 } & DUR & 0.0616 & 0.1407 & 0.971 \\
& GHA & KTC & 0.2629 & 0.1580 & 0.360 \\
\hline
\end{tabular}




\begin{tabular}{|c|c|c|c|c|c|}
\hline & & DFR & -0.0616 & 0.1407 & 0.971 \\
\hline & DUR & GHA & -0.1988 & 0.1513 & 0.562 \\
\hline & & KTC & 0.2012 & 0.1758 & 0.665 \\
\hline & & DFR & -0.2629 & 0.1580 & 0.360 \\
\hline & KTC & GHA & -0.4000 & 0.1674 & 0.101 \\
\hline & & DUR & -0.2012 & 0.1758 & 0.665 \\
\hline \multirow{12}{*}{$\begin{array}{c}\text { Construction Delivery } \\
\text { (CD) }\end{array}$} & & GHA & 0.0453 & 0.1052 & 0.973 \\
\hline & DFR & DUR & 0.1545 & 0.1137 & 0.534 \\
\hline & & KTC & 0.2688 & 0.1276 & 0.174 \\
\hline & & DFR & -0.0453 & 0.1052 & 0.973 \\
\hline & GHA & DUR & 0.1092 & 0.1222 & 0.808 \\
\hline & & KTC & 0.2235 & 0.1353 & 0.366 \\
\hline & & DFR & -0.1545 & 0.1137 & 0.534 \\
\hline & DUR & GHA & -0.10925 & 0.1222 & 0.808 \\
\hline & & KTC & 0.1143 & 0.1420 & 0.852 \\
\hline & & DFR & -0.2688 & 0.1276 & 0.174 \\
\hline & KTC & GHA & -0.2235 & 0.1353 & 0.366 \\
\hline & & DUR & -0.1143 & 0.1420 & 0.852 \\
\hline \multirow{12}{*}{$\begin{array}{l}\text { Project Sustainability } \\
\text { (PS) }\end{array}$} & & DFR & -0.0086 & 0.1023 & 1.000 \\
\hline & DFR & DUR & 0.0708 & 0.1106 & 0.918 \\
\hline & & KTC & -0.0974 & 0.1241 & 0.861 \\
\hline & & DFR & 0.0086 & 0.1023 & 1.000 \\
\hline & GHA & DUR & 0.0794 & 0.1189 & 0.908 \\
\hline & & KTC & -0.0889 & 0.1316 & 0.905 \\
\hline & & DFR & -0.0708 & 0.1106 & 0.918 \\
\hline & DUR & GHA & -0.0794 & 0.1189 & 0.908 \\
\hline & & KTC & -0.1683 & 0.1381 & 0.620 \\
\hline & & DFR & 0.0974 & 0.1241 & 0.861 \\
\hline & KTC & GHA & 0.0889 & 0.1315 & 0.905 \\
\hline & & DUR & 0.1683 & 0.1381 & 0.620 \\
\hline
\end{tabular}

RISA-Road Infrastructure and Support Agencies. The mean difference is significant at 0.05 level.

poor quality and safety measures as some of the characteristic weaknesses inherent in this method. The over-reliance on this system was demonstrated in Figure 6 , where $91 \%$ of the respondents depended on it for the management of road projects.

In fact, only about a quarter of the respondents acknowledged integrating value, which comprises cost, time and quality, into the road management process. Value Engineering project management process, which incorporates 
cost, time and quality, is an innovative and sustainable technique for establishing the best functional balance among the desired parameters. Although the respondents had some level of knowledge on VE, their practical application of the system was limited. The Optimum Value benefits of project management process can be expressed as Confidence Level in Contract Compliance, Implementation Level of Construction Delivery and Effectiveness Level of Project Sustainability. Figure 7 shows that all the four categories of Road Professionals (DFR, GHA, DUR and KTC) perceived VE to be beneficiary to road project management. On a 5-point scale, the professionals rated CL, IL and EL high with respective mean scores of 3.91, 3.87 and 4.10. The Confident Level (CL) measures the Contract Compliance in relation to conformity with agreed rules, specifications, contract conditions and any implied needs of the client. The GHA rated CL utmost with a mean score of 4.09 while the KTC scored it least at 3.69. DFR and DUR scored it 3.95 and 3.89 respectively. Construction Delivery is expressed as Implementation Level (IL) and considers prospects to achieve effective service organization towards project execution. The importance of $\mathrm{CD}$ for optimum VE was recognized by the RP and expressed in the high mean scores of IL 3.99 (DFR), 3.94 (GHA), 3.89 (DUR) and 3.72 (KTC). Project Sustainability is measured as Effectiveness Level (IL). It comprises pronounced procedures for addressing the needs of the present generation without compromising future economic, social and environmental impacts of the project. DFR, GHA and KTC scored IL as 4.32, 4.33 and 4.42 respectively. Only DUR gave a relatively low mean score of 3.31. The mean scores of the four groups of Road Professionals (DFR, GHA, DUR and KTC) in respect of IL produced the least variation with DFR scoring it the highest of 3.99 and KTC had the least of 3.72. The highest score for CL was 4.09 (GHA) with the lowest being 3.69 (KTC). Apart from DUR (3.31), the other three groups of the professionals rated EL very high (exceeding 4). The overall high mean score ratings for all three VE benefit parameters (CL, IL and EL) can be interpreted as an endorsement of the VE project management process as a superior substitute to Cost in realizing Optimum Value benefits on Road Projects in Ghana.

The Analysis of Variance (ANOVA) was used to analyze any variations in the scores from DFR, GHA, DUR and KTC sources by comparing the significant levels of the means of the groups. By this method, the effects of the independent variables (DFR, GHA, DUR and KTC) on the dependent variables (CL, IL and EL) were analyzed. In Table 2, descriptive statistics on the means, standard deviations and standard errors at $95 \%$ confidence levels for the dependent variables (CC, CD and PS) were provided for the separate independent groups (DFR, GHA, DUR and KTC). Also included in Table 2 were their totals. The mean totals for CC, CD and PS were 3.9348, 3.9031 and 4.3268 respectively. Their corresponding group standard errors were found to $0.05371,0.04301$ and 0.03951 . Table 3 which shows the output of the ANOVA analysis indicated the statistically significant difference between the group means. There were no statistically significant differences in the means between CC and the group of independent 
variables $(F(3,30)=1.974, \mathrm{p}=0.139)$, and $\mathrm{CD}$ and the independent variables $(F$ $(3,30)=1.761, \mathrm{p}=0.176)$. The third dependent variable (PS) too had no statistically significant difference between the four independent groups of respondents (DFR, GHA, DUR and KTC) as $F(3,30)=0.498$ and $\mathrm{p}=0.686(\mathrm{p}>0.05)$. Table 4, which comprised the multiple comparisons of specific individual groups, confirmed that there were no significant differences between the responses of the DFR, GHA, DUR and KTC. There were consistency, certainty and reliability in the responses. The ANOVA tests, therefore, showed that there was no variability in the responses of Road Professionals regarding CC, CD and PS benefits of VE.

\section{Conclusion}

The fixation on traditional Cost Control techniques for road project management restricts all aspects of the work to only budget consideration with little attention to the greater optimization deliberation. This does not only affect the quality or value but has the tendency to render projects functionally unsustainable. On the other hand, Optimum Value benefits can be accomplished through the VE process. Value Engineering (VE) project management process is an innovative, systematic and sustainable methodology for establishing the best functional balance among the desired features or requirements of a project. The benefits of VE were assessed on three optimum value parameters of Contract Compliance (CC), Construction Delivery (CD) and Project Sustainability (PS). The Confident Level (CL) of CC, Implementation level (IL) of CD and Effectiveness Level (EL) of PS were all scored high by the Road Professionals from DFR, GHA, DUR and KTC. Consequently, Road Professionals under MRH appraised that the VE project management process is a beneficial method of realizing Optimum Value on Road Projects in Ghana. Unlike the Cost Control process, VE isolates design deficiencies, meets the stated and implied needs of clients, and improves quality and functional performance. A VE implementation guide for Road Projects in Ghana is therefore recommended. The study will not only deepen and expand the innovative frontiers of VE but its application will help to identify and eliminate unnecessary cost and improve upon the functional viability of road projects.

\section{Acknowledgements}

The authors are grateful to the Agencies under the Ministry of Roads and Highways (MRH) in Ghana for facilitating the data collection of this paper.

\section{Conflicts of Interest}

The authors declare no conflicts of interest regarding the publication of this paper.

\section{References}

[1] Koskela, L.J. and Howell, G. (2002) The Underlying Theory of Project Management 
Is Obsolete. Proceedings of PMI Research Conference, Seattle, Washington, June 2002, 293-302.

http://usir.salford.ac.uk/id/eprint/9400/1/2002_The_underlying_theory_of_project_ management_is_obsolete.pdf

[2] Liu, G. and Shen, Q. (2005) Value Management in China: Current State and Future Prospect. Management Decision Journal, 43, 603-610.

https://www.emerald.com/insight/content/doi/10.1108/00251740510593585/full/ht ml?skipTracking=true https://doi.org/10.1108/00251740510593585

[3] Chileshe, N., Berko, P.D. and Haupt, T. (2010) Causes of Project Cost Overruns within the Ghanaian Road Construction Sector. Proceedings: The 5 th Built Environment Conference, Durban, 18-20 July 2010, 66.

http://www.asocsa.org/documents/proceedings/2010-ASOCSA-5thBE-conferenceDurban-RSA.pdf

[4] Dzah, B.D. (2005) The Potential of Value Engineering in the Ghanaian Construction Industry. M.Sc. Thesis, Department of Building Technology, KNUST-Kumasi.

[5] Kissi, E., Bannor, B.E. and Adjei-Kumi, T. (2015) Strategies for Implementing Value Management in the Construction Industry of Ghana. Proceedings of the DII-2015 Conference on Infrastructure Development and Investment Strategies for Africa, Livingstone, 16-18 September 2015, Vol. 2, 225-267.

https://www.researchgate.net/publication/305476358_Strategies_for_Implementing _Value_Management_in_the_Construction_Industry_of_Ghana

[6] Annor-Asubonteng, J., Tengan, C. and Asigri, T.M. (2018) Investigating the Cost Management Practices of Indigenous Firms in the Ghanaian Construction Industry. Journal of Economics and Behavioral Studies, 10, 179-186.

https://www.researchgate.net/publication/328956008_Investigating_the_Cost_Mana gement_Practices_of_Indigenous_Firms_in_the_Ghanaian_Construction_Industry https://doi.org/10.22610/jebs.v10i5(J).2507

[7] Offei-Nyako, K., Ohene Tham, L.C., Bediako, M., Adobor, C.D. and Oduro Asamoah, R. (2016) Deviations between Contract Sums and Final Accounts: The Case of Capital Projects in Ghana. Journal of Construction Engineering, 2016, Article ID: 2814126. http://downloads.hindawi.com/archive/2016/2814126.pdf https://doi.org/10.1155/2016/2814126

[8] Chan, I.Y.S., Leung, M. and Yuan, T. (2014) Structural Relationships between Cultural Values and Coping Behaviours of Professionals in the Stressful Construction Industry. Engineering, Construction and Architectural Management Journal, 21, 133-151. https://doi.org/10.1108/ECAM-07-2012-0069

https://www.emerald.com/insight/content/doi/10.1108/ECAM-07-2012-0069/full/html

[9] Jaapar, A. (2000) The Case for Value Management to Be Included in Every Construction Project Design Process. Published Thesis (MSc), Universiti Teknologi Mara, Kuala Lumpur.

http://ir.uitm.edu.my/id/eprint/2636/1/TM_AINI\%20JAAPAR\%20AP\%2000_5\%20 1.pdf

[10] Ji, S. (2002) Design Value Engineering in Korea. Journal of Construction Management and Engineering, 55, 225-230. https://doi.org/10.2208/jscej.2002.707_225 https://www.jstage.jst.go.jp/article/jscej1984/2002/707/2002_707_225/_pdf

[11] Gibbons, P.M., Kennedy, C., Burgess, S.C. and Godfrey, P. (2012) Developing an Asset Management Value Improvement Model [a-VIM] Approach for an Airport Operational Engineering Environment. International of Journal of Quality and Reliability Management, 29, 797-819. https://doi.org/10.1108/02656711211258544 
https://www.emerald.com/insight/content/doi/10.1108/02656711211258544/full/html

[12] Bowen, P., Catell, K., Jay, I. and Edwards, P. (2011) Value Management in the South African Manufacturing Industry: Exploratory Findings. Management Decision Journal, 49, 6-28. https://doi.org/10.1108/00251741111094419 https://www.emerald.com/insight/content/doi/10.1108/00251741111094419/full/html

[13] Kelly, J., Male, S. and Graham, D. (2004) Value Management of Construction Projects. Blackwell Science Publishing Company Ltd., Hoboken. https://doi.org/10.1002/9780470773642

[14] Adjei, K.O., Aigbavboa, C. and Thwala, W.D. (2018) The Challenges of Cost Control Practice in the Construction Industry: A Literature Review. 4th International Conference on Applied Sciences and Technology, Vol. 4, No. 1, 14-24.

https://www.researchgate.net/publication/324587769_The_Challenges_of_Cost_Co ntrol_Practice_in_the_Construction_Industry_A_Literature_Reviewu

[15] Leung, M. and Yu, J. (2014) Value Methodology in Public Engagement for Construction Development Projects. Built Environment Project and Asset Management, 4, 55-70. https://doi.org/10.1108/BEPAM-05-2012-0033 https://www.emerald.com/insight/content/doi/10.1108/BEPAM-05-2012-0033/full/ $\underline{\mathrm{html}}$

[16] Amoatey, C.T. and Ankrah, A.N.O. (2017) Exploring Critical Road Project Delay Factors in Ghana. Journal of Facilities Management, 15, 110-127.

https://www.researchgate.net/profile/Charles_Amoatey/publication/315175955_Explor ing_critical_road_project_delay_factors_in_Ghana/links/5cd569fb92851c4eab91d66 2/Exploring-critical-road-project-delay-factors-in-Ghana.pdf https://doi.org/10.1108/JFM-09-2016-0036

[17] Narh, A.K. (2014) Innovative Financing of Road Projects in the Ghanaian Construction Industry. Published Thesis (MSc), Department of Building Technology, KNUST-Kumasi.

http://dspace.knust.edu.gh/bitstream/123456789/6774/1/Albert\%20Kudjo\%20Narh. pdf

[18] Buertey, J.I.T. and Asare, S.K. (2014) Road Infrastructural Delivery in Ghana: Trends and Projections. International Journal of Engineering and Technical Research, 2, 1-7.

https://www.academia.edu/9776786/Road_Infrastructural_Delivery_in_Ghana_Tre nds_and_Projections

[19] MRH-PBB (2018) Ministry of Roads and Highways-MRH. Program Based Budget (PBB) Estimates, Medium Term Expenditure Framework (MTEF) for 2018-2021, Republic of Ghana.

https://www.mofep.gov.gh/sites/default/files/pbb-estimates/2018/2018-PBB-MRH.pdf

[20] Society of American Value Engineers (SAVE)-International, Mount Royal (2012). https://www.value-eng.org

[21] Kasi, M. (2009) Function Approach to Transportation Projects, a Value Engineering Guide. Iuniverse Inc., New York, Bloomington.

[22] Salvatierra-Garrido, J. and Pasquire, C. (2011) Value Theory in Lean Construction. Journal of Financial Management of Property and Construction, 16, 8-18.

https://www.researchgate.net/publication/235288596_Value_theory_in_lean_constr uction https://doi.org/10.1108/13664381111116043

[23] Rane, N.L. and Attarde, P.M. (2016) Application of Value Engineering in Construction Projects. International Journal of Engineering and Management Research, 6, 25-29. 
https://www.ijert.org/research/application-of-value-engineering-in-construction-jo b-sites-a-case-study-IJERTV6IS020054.pdf

[24] Mahdi, I.M., Heiza, K. and Elenan, N.A. (2015) Value Engineering and Value Analysis of Vertical Slip form Construction System. International Journal of Application or Innovation in Engineering \& Management (IJAIEM), 4, 200-212.

https://www.academia.edu/20102126/Value_Engineering_and_Value_Analysis_of_ Vertical_Slip_Form_Construction_System

[25] Mansour, D.M., Rashid, I.A. and Arafat, H. (2013) Value Engineering Analysis in the Construction of Box-Girder Bridges. International Journal of Latest Trends in Engineering and Technology, 2, 65-72.

https://pdfs.semanticscholar.org/ed59/9a61df77f8eb9a19837bcb2c361e8d76fab6.pdf

[26] Kashiwagi, D. and Savicky, J. (2003) The Cost of "Best Value" Construction. Journal of Facilities Management, 2, 285-297.

https://www.researchgate.net/publication/235308093_The_cost_of_'best_value'_con struction https://doi.org/10.1108/14725960410808267

[27] Male, S., Kelly, J., Gronqvist, M. and Graham, D. (2007) Managing Value as a Management Style for Projects. International Journal of Project Management, 25, 107-114. https://www.sciencedirect.com/science/article/abs/pii/S0263786306001323 https://doi.org/10.1016/j.ijproman.2006.09.001

[28] Benstin, M., Benston, D. and Haraburda, S. (2011) Using Value Engineering to Reduce Life Cycle Cost. Defense AT \& L.

https://www.researchgate.net/publication/228399561_Using_Value_Engineering_to _Reduce_Life_Cycle_Cost

[29] Ashworth, A. (2004) Cost Studies of Buildings. 4th Edition, Pearson Prentice Hall, Upper Saddle River.

[30] PMBOK Guide (2008) A Guide to Project Management Body of Knowledge. 4th Edition, Project Management Institute, Inc., Newtown Square.

https://www.works.gov.bh/English/ourstrategy/Project\%20Management/Document s/Other\%20PM\%20Resources/PMBOKGuideFourthEdition_protected.pdf

[31] Rangwala, S.C., Rangwala, K.S. and Rangwala, K.K. (2009) Estimating, Costing and Valuation: Professional Practice. 12th Edition, Charotar Publishing House PVT Ltd., Gujurat.

https://catal0g.info/downloads/Estimating\%20Costing\%20And\%20Valuation\%20C harotar\%20Publishing\%20.pdf

[32] Whitty, S.J. (2011) On a New Philosophy of Managing Projects in Business. International Journal of Managing Projects in Business, 4, 524-533.

https:/www.emerald.com/insight/content/doi/10.1108/17538371111144210/full/html https://doi.org/10.1108/17538371111144210

[33] Mahamadu, A.M., Mahdjoubi, L., Booth, C. and Fewings, P. (2015) Integrated Delivery of Quality, Safety and Environment through Road Sector Procurement: The case of Public Sector Agencies in Ghana. Journal of Construction in Developing Countries, 20, 1-24. https://uwe-repository.worktribe.com/output/843115

[34] Agyeman, S., Asare, E.K. and Ankomah, E.N. (2016) The Effects of Design Information on Reliability of Progress and Cost Estimates of Construction Projects: The Case of Two Civil Engineering Projects. American Journal of Civil Engineering, 4, 326-336. https://doi.org/10.11648/j.ajce.20160406.19 https://pdfs.semanticscholar.org/74ac/5ff322941c72d037a84b24d2b2e7c96550b7.pdf

[35] Czuchry, A.J. and Yasin, M.M. (2003) Managing the Project Management Process. 
Industrial Management and Data system Journal, 103, 39-46. https://www.emerald.com/insight/content/doi/10.1108/02635570310456887/full/html https://doi.org/10.1108/02635570310456887

[36] Annappa, C. and Panditrao, K. (2012) Application of Value Engineering for Cost Reduction-A Case Study of Universal Testing Machine. International Journal of Advances in Engineering \& Technology, 4, 618-629.

https://www.researchgate.net/publication/283008884_Application_of_value_engine ering_for_cost_reduction-a_case_study_of_universal_testing_machine

[37] Shen, Q.G. and Yu, A.T.W. (2012) Value Management: Recent Developments and Way Forward. Construction Innovation Journal, 12, 264-271.

http://ira.lib.polyu.edu.hk/bitstream/10397/6715/1/Editorial_Shen.Yu._Vol.12_no.3 .2_article.pdf https://doi.org/10.1108/14714171211244631

[38] Wilson, D.C. (2005) Value Engineering Applications in Transportation: A Synthesis of Highway Practice. NCHRP 352, NCE Limited, Markham. https://www.nap.edu/read/13869/chapter/1\#ii

[39] Dell'Isola, A.J. (1982) Value Engineering in the Construction Industry. Third Edition, Van Nostrand and Reinhold Co., New York.

[40] Zimmerman, L.W. and Hart, G.D. (1982) Value Engineering: A Practical Approach for Owners, Designers and Contractors. Van Nostrand and Reinhold Co., New York.

[41] Atabay, S. and Galipogullari, N. (2013) Application of Value Engineering in Construction Projects. Journal of Traffic and Transportation Engineering, 1, 39-48.

https://www.researchgate.net/publication/285275968_Application_of_Value_Engin eering_in_Construction_Projects https://doi.org/10.17265/2328-2142/2013.12.005

[42] Yu, A.T.W., Shen, Q., Kelly, J. and Hunter, K. (2005) Application of Value Management in Project Briefing. Facilities Journal, 23, 330-342. https://www.emerald.com/insight/content/doi/10.1108/02632770510600281/full/html https://doi.org/10.1108/02632770510600281

[43] Wao, J. (2017) Enhancing the Function Analysis and Identification Phase of the Value Engineering Methodology. 57th SAVE International Annual Conference: SA VE Value Summit, Philadelphia, 25-30 August 2017, 1-7.

https://www.researchgate.net/publication/321992616_Enhancing_the_Function_An alysis_and_Identification_Phase_of_the_Value_Engineering_Methodology

[44] SAVE (2007) Value Standard and Body of Knowledge. SAVE International, Mount Royal. http://www.pinnacleresults.com/images/VE_Standard_from_SAVE.pdf

[45] Jarboe, R.R. (1978) Value Engineering in Highway Construction. Army Corps of Engineers, Tulsa.

https://docs.lib.purdue.edu/cgi/viewcontent.cgi?article=3172\&context=roadschool

[46] Dlugatch, I. (1973) Methodology for Value Engineering. Journal of IEEE Transactions on Reliability, 22, 20-23. https://doi.org/10.1109/TR.1973.5216017

[47] Borza, J. (2011) FAST Diagrams: The Foundation for Creating Effective Function Models. General Dynamics Land Systems, Value Innovation. Detroit, 28-29 November 2011, 1-10.

http://new.aitriz.org/documents/TRIZCON/Proceedings/2011-06_FAST-DiagramsThe-Foundation-for-Creating-Effective-Function-Models.pdf

[48] Bytheway, C. (2007) FAST Creativity and Innovation: Rapidly Improving Processes, Product Development and Solving Complex Problems. J. Ross Publishing, Fort 
Lauderdale.

[49] Chen, W., Chang, P. and Huang, Y. (2010) Assessing the Overall Performance of Value Engineering Workshops for Construction Projects. International Journal of Project Management, 28, 514-527. https://doi.org/10.1016/j.ijproman.2009.08.005 https://www.researchgate.net/profile/Wei_Tong_Chen/publication/248345307_Asse ssing_the_overall_performance_of_value_engineering_workshops_for_constructio n_projects/links/5c636ef092851c48a9cfbab0/Assessing-the-overall-performance-ofvalue-engineering-workshops-for-construction-projects.pdf

[50] Ajay, S. and Micah, B. (2014) Sampling Techniques and Determination of Sample size in Applied Statistics Research: An Overview. International Journal of Economics, Commerce and Management, 2, 1-22.

http://ijecm.co.uk/wp-content/uploads/2014/11/21131.pdf

[51] Fellows, R. and Liu, A. (2008) Research Methods for Construction. 3rd Edition, Blackwell Publishing Limited, Hoboken.

[52] Bickel, P.J. and Lehmann, E.L. (2012) Descriptive Statistics for Nonparametric Models I. Introduction. In: Selected Works of EL Lehmann, Springer, Boston, 465-471. https://core.ac.uk/download/pdf/81730402.pdf

https://doi.org/10.1007/978-1-4614-1412-4_42

[53] Adeyemi, T.O. (2009) Inferential Statistics for Social and Behavioural Research. Research Journal of Mathematics and Statistics, 1, 47-54.

https://pdfs.semanticscholar.org/1869/f09205ffbd289f838077c9180a6817491796.pdf

[54] Martin, C.G. and Games, P.A. (1977) ANOVA Tests for Homogeneity of Variance: Nonnormality and Unequal Samples. Journal of Educational Statistics, 2, 187-206. https://doi.org/10.3102/10769986002003187 